\title{
ORGANIC MATTER FRACTIONS IN A QUARTZIPSAMMENT UNDER CULTIVATION OF IRRIGATED MANGO IN THE LOWER SÃO FRANCISCO VALLEY REGION, BRAZIL
}

\author{
José Alberto Ferreira Cardoso(1), Augusto Miguel Nascimento Lima(2)*, Tony Jarbas Ferreira \\ Cunha(3), Marcos Sales Rodrigues(2), Luis Carlos Hernani(4), Andre Julio do Amaral(4) and \\ Manoel Batista de Oliveira Neto(4) \\ (1) Universidade Federal do Vale do São Francisco, Campus Ciências Agrárias, Programa de Pós-graduação em Engenharia Agrícola, \\ Juazeiro, Bahia, Brasil. \\ (2) Universidade Federal do Vale do São Francisco, Colegiado de Engenharia Agronômica, Campus Ciências Agrárias, Petrolina, \\ Pernambuco, Brasil. \\ (3) Empresa Brasileira de Pesquisa Agropecuária, Centro Nacional em Pesquisa do Semiárido, Petrolina, Pernambuco, Brasil. \\ (4) Empresa Brasileira de Pesquisa Agropecuária, Centro Nacional de Pesquisa de Solos, Rio de Janeiro, Rio de Janeiro, Brasil. \\ * Corresponding author. \\ E-mail: augusto.lima@univasf.edu.br
}

\begin{abstract}
Improper land use has lead to deterioration and depletion of natural resources, as well as a significant decline in agricultural production, due to decreased soil quality. Removal of native vegetation to make way for agricultural crops, often managed inadequately, results in soil disruption, decreased nutrient availability, and decomposition of soil organic matter, making sustainable agricultural production unviable. Thus, the aim of the present study was to evaluate the impact of growing irrigated mango (over a 20 year period) on the organic carbon $(\mathrm{OC})$ stocks and on the fractions of soil organic matter (SOM) in relation to the native caatinga (xeric shrubland) vegetation in the Lower São Francisco Valley region, Brazil. The study was carried out on the Boa Esperança Farm located in Petrolina, Pernambuco, Brazil. In areas under irrigated mango and native caatinga, soil samples were collected at the 0-10 and 10-20 cm depths. After preparing the soil samples, we determined the OC stocks, carbon of humic substances (fulvic acid fractions, humic acid fractions, and humin fractions), and the light and heavy SOM fractions. Growing irrigated mango resulted in higher OC stocks; higher $\mathrm{C}$ stocks in the fulvic acid, humic acid, and humin fractions;
\end{abstract}


and higher $\mathrm{C}$ stocks in the heavy and light SOM fraction in comparison to native caatinga, especially in the uppermost soil layer.

\author{
Keywords: Mangifera indica, organic carbon, humic substances, heavy fraction, semiarid \\ region.
}

\title{
RESUMO: FRAÇÕES DA MATÉRIA ORGÂNICA EM UM NEOSSOLO QUARTZARÊNICO, SOB CULTIVO DE MANGUEIRA IRRIGADA NO VALE DO SUBMÉDIO SÃO FRANCISCO
}

\begin{abstract}
A utilização inadequada das terras tem ocasionado deterioração e esgotamento dos recursos naturais existentes, além da queda significativa da produção agrícola, em razão da piora da qualidade do solo. A remoção da vegetação natural para dar lugar a cultivos agrícolas muitas vezes manejados de forma inadequada resulta na desestruturação do solo, diminuição da disponibilidade de nutrientes e decomposição da matéria orgânica do solo, inviabilizando a sustentabilidade da produção agrícola. Assim, este estudo teve por objetivo avaliar o impacto do cultivo de mangueira irrigada (20 anos de idade) no estoque de carbono orgânico (CO) e nas frações da matéria orgânica do solo (MOS), em relação à caatinga nativa na região do Vale do Submédio São Francisco. O estudo foi realizado na Fazenda Boa Esperança localizada em Petrolina, PE. Nas áreas sob mangueira irrigada e caatinga nativa, foram coletadas amostras de solo nas camadas de 0-10 e 10-20 cm. Após a coleta e o preparo das amostras de solo, foram determinados os estoques de CO, C das substâncias húmicas (fração ácidos fúlvicos, ácidos húmicos e humina) e frações leve e pesada da MOS. O cultivo de mangueira irrigada promoveu maiores estoques de CO, C das frações ácidos fúlvicos, ácidos húmicos e humina, $C$ da fração pesada e matéria orgânica leve, quando comparado à caatinga nativa, principalmente na camada mais superficial do solo.
\end{abstract}

Keywords: Mangifera indica, carbono orgânico, substâncias húmicas, fração pesada, semiárido.

\section{INTRODUCTION}

Growing of mango (Mangifera indica) under irrigated conditions in the Lower São Francisco River Valley has intensified in the past years. The region represented mainly by the states of Pernambuco and Bahia is responsible for around $93 \%$ of the production and $84 \%$ of Brazilian exports of mango (Agrianual, 2010). The Brazilian semiarid region is characterized by low rainfall, high evapotranspiration and temperature, and low biomass production (Araújo Filho, 2002). In this region, inadequate soil management may contribute to reduction in the stocks of soil organic matter (SOM).

As a fundamental component for maintenance of soil quality, SOM is involved in diverse physical, chemical, and biological processes. Since it is very sensitive to soil management practices, SOM undergoes imbalances in its supply and changes in decomposition rates, which may affect the productivity of agroecosystems (Roscoe and Machado, 2002). Although a productive soil is composed of less than $5 \%$ SOM, SOM determines crop yield through its influence on the chemical and physical properties of the soil (UENF, 2013). The SOM and its different compartments supply nutrients to plants, structure the soil, and control the flow of water and gases between the Earth's surface and the atmosphere (Gama-Rodrigues et al.,
2005). In longer cycle crops, such as mango, SOM is closely related to sustainability of production (Mendham et al., 2004).

The substitution of native forest for agriculture may lead to a reduction in soil $\mathrm{C}$ stocks, primarily in response to acceleration in the rate of decomposition caused by soil tillage, greater aeration, and physical exposure of SOM to decomposing microorganisms (Carneiro et al., 2009). In a study undertaken in the municipality of Paraipaba, CE, Brazil, in an area of hypoxerophytic schrubland (Caatinga hipoxerófila) with banana, cashew, guava, mango, soursop, and sapodilla, Bernardi et al. (2007) observed that the change from caatinga (xeric shrubland) to different types of use changed the organic carbon (OC) stocks. After six years of cultivation, the soils under guava, banana, cashew, and mango showed declines of $12-24 \%$ in OC stocks in the layer from $0-40 \mathrm{~cm}$ when compared to caatinga. The soils under soursop and sapotilla showed a 5 and $9 \%$ decline in the OC stock in relation to caatinga. Soil tillage leads to degradation of organic matter and causes losses in OC, in spite of the annual deposit of organic residues from the fruit orchards (Bernardi et al., 2007). Evaluating the impact of banana and citrus orchards in relation to native vegetation (remaining from the Atlantic Forest) in the Plateau of Neópolis, Sergipe, Brazil, Guimarães et al., (2014) observed that an irrigated banana plantation resulted in a $14 \%$ increase in the OC content in the 
0-10 cm layer when compared to native vegetation. In contrast, in an irrigated citrus orchard, there was a reduction in OC content of approximately $38 \%$ in the same layer. Differences in OC stocks were explained by the amount of organic residues deposited on the soil surface and by the plant canopies, which were greater in the area under banana.

Many studies have evaluated the SOM dynamic under annual crops in regions with high rainfall (Freixo et al., 2002; Carneiro et al., 2009). Nevertheless, little is known in respect to SOM stocks and their dynamic in sandy soils under irrigated orchards in semiarid regions. Fruit orchards, such as mango, in irrigated areas have represented a profitable alternative for farmers in this region, where research information in regard to $\mathrm{C}$ stocks of the diverse SOM fractions is scarce, indicating the need for more studies. In a system with an adequate level of technology and with a high density of irrigated mango growing, such as the São Francisco River Valley, irrigation, fertilization, pruning, and weed control with a view toward adequate production constitute management practices performed in each crop production cycle, which result in deposit and maintenance of large amounts of plant residues on the soil surface, and this may increase the SOM stocks (Franzluebbers et al., 2007).

Considering that SOM is formed of different compartments with different cycling times and that the most stable SOM compartments (humic substances) are quantitatively dominant under tropical conditions, direct determination of losses and gains of SOM through change in usage might not be easily perceived. Consequently, fractionation of SOM may be an important tool for detecting changes in the SOM stocks in the short term and for directing research with a focus on studying SOM (Benites et al., 2010). In a study carried out in the Plateau of Neópolis, SE, evaluating the impact of eight years of banana and citrus orchards on the soil organic matter fractions in relation to the Atlantic Forest, Guimarães et al., (2014) did not observe a difference in the OC content in the 10-30 cm depth layer when comparing the banana plantation to native forest. In contrast, in this same layer, particulate organic matter was $29 \%$ greater in the soil under native forest when compared to the banana orchard, and this fraction may be used as an indicator of soil quality. A greater amount of particulate organic matter in the soil under native forest was explained as being due to greater root systems and deposit of root exudates under native vegetation.

Although growing of irrigated mango is of great socio-economic importance in the Lower São Francisco River Valley region, little is known about the impact of this activity on the $\mathrm{C}$ stocks of the SOM fractions. In this context, the aim of the present study was to evaluate the impact of growing irrigated mango on the organic carbon (OC) stocks, the $\mathrm{C}$ in humic substances, and the $\mathrm{C}$ of the heavy fraction and light fraction of SOM in comparison to the native caatinga in the Lower São Francisco Valley region.

\section{MATERIAL AND METHODS}

The present study was carried out on the Boa Esperança Farm, located in the municipality of Petrolina, PE, Brazil. The area of study is located at the geographic coordinates of latitude $9^{\circ} 19^{\prime} 55.8^{\prime \prime}$ S and longitude $40^{\circ} 26^{\prime} 54.2^{\prime \prime} \mathrm{W}$, where the soil was classified as Neossolo Quartzarênico órtico típico (Quartzipsamment) (Santos et al., 2013). Climate in the region is BSwh (semiarid) according to the Köppen climate classification, with a low rainfall index throughout the year $(400$ to $800 \mathrm{~mm})$. It has a mean annual temperature of $26.3^{\circ} \mathrm{C}$, relative air humidity of around $71 \%, 2,774$ sunlight hours, mean annual evapotranspiration of $7.5 \mathrm{~mm} /$ day, and wind speed of $19.7 \mathrm{~km} / \mathrm{h}$.

Soil samples were collected in November 2012 in two areas of the Boa Esperança Farm, one with irrigated mango (20 years of growth) and another with native forest (hypoxerophytic schrubland), located approximately $150 \mathrm{~m}$ from one another and under the same soil classification. It was assumed that 20 years of growing irrigated mango would allow verification of its effect on $\mathrm{C}$ stocks of the SOM fractions in relation to native forest. Prior to the irrigated mango plantation, the area was occupied by native caatinga up to the middle of 1993. After removal of the caatinga, the soil was tilled (plowed and disked) for planting mango. The soil $\mathrm{pH}$ was then amended through application of dolomitic limestone to raise $\mathrm{pH}$ to 5.5-6.0 using the base saturation method (Alvarez V and Ribeiro, 1999). In addition to soil amendment at the time of planting, soil $\mathrm{pH}$ was amended annually after each production cycle, when necessary. Mango (Tommy Atkins) was planted at a spacing of $5.0 \times 10.0 \mathrm{~m}$, with the addition of cattle manure $(20 \mathrm{~L}$ plant/hill) and fertilization at planting $(\mathrm{P}, \mathrm{K}, \mathrm{S})$ according to soil analysis. In addition, fertilization for fruit production is carried out annually $\left(650 \mathrm{~g} / \mathrm{pl}\right.$ of $\mathrm{Ca}\left(\mathrm{NO}_{3}\right)_{2}, 800 \mathrm{~g} / \mathrm{pl}$ of $\mathrm{KCl}$, $450 \mathrm{~g} / \mathrm{pl}$ of $\mathrm{MgSO}_{4}$, and $50 \mathrm{~g} / \mathrm{pl}$ of $\mathrm{H}_{3} \mathrm{BO}_{3}$ ) to meet the nutritional requirements of the crop (expected yield $>30 \mathrm{t} / \mathrm{ha}$ ), according to the recommendations of Silva et al. (2002). In addition, $20 \mathrm{~L} / \mathrm{pl}$ of goat manure is added annually in the plant row (under the canopy). The irrigation system used is localized (microspray), seeking to meet the water requirements of the plant. Flowering of the mango is always induced by application of calcium nitrate and potassium nitrate (Albuquerque et al., 2002). The plant row and between the plant row were always kept free of weeds through manual and mechanical weeding. After harvest, the plants are pruned annually, leaving the organic residue in the plant row. 
The present study is composed of two treatments (irrigated mango and native caatinga), with 10 replications (10 georeferenced points). In the areas under irrigated mango and caatinga, soil samples were collected in the $0-10$ and $10-20 \mathrm{~cm}$ depth soil layers. It should be noted that in the area under irrigated mango, soil samples were collected in the plant row (under the canopy of the mango); and, in the caatinga area, a subsample was collected at a georeferenced point and two others in a radius of 1 $\mathrm{m}$ from that point (Figure 1). Three samples were collected from each depth to obtain a compound sample for each georeferenced point. The soil samples were air dried, broken up, homogenized, and passed through a sieve with a $2.0 \mathrm{~mm}$ screen. Undisturbed soil samples were also collected (with soil sample rings) in the aforementioned soil layers for determination of soil bulk density $(\mathrm{Bd})$ by the core method, following procedures from Claessen et al. (1997).

The TFSA samples were ground up and passed through a sieve with a 100 mesh $(0.149 \mathrm{~mm})$ for determination of organic $\mathrm{C}(\mathrm{OC})$ by the wet oxidation method, with external heating (Yeomans and Bremner, 1988).

Fractionation of humic substances was carried out according to the method suggested by the International Humic Substances Society (Swift, 1996) adapted by Benites et al. (2003). From this fractionation, we obtained the fulvic acid fraction (FAF), humic acid fraction (HAF), and humin fraction (HF), based on the solubility in acid or alkaline solutions. The $\mathrm{C}$ content in each humic fraction was determined by the wet oxidation method with external heating (Yeomans and Bremner, 1988). The $\mathrm{C}_{\mathrm{HAF}} / \mathrm{C}_{\mathrm{FAF}}, \mathrm{C}_{\mathrm{HF}} /\left(\mathrm{C}_{\mathrm{FAF}}+\mathrm{C}_{\mathrm{HAF}}\right)$, and $\mathrm{C}_{\mathrm{FAF}}+\mathrm{C}_{\mathrm{HAF}}+\mathrm{C}_{\mathrm{HF}} / \mathrm{C}_{\text {Total }}$ ratios were calculated (Labrador-Moreno, 1996).

In the TFSA samples, physical fractionation of the SOM was also carried out, according to the method proposed by Demolinari et al. (2008). Concisely, the method consisted of shaking $15 \mathrm{~g}$ of TFSA with 30 $\mathrm{mL}$ of distilled water in centrifuge tubes for $16 \mathrm{~h}$ in a vertical shaker, without making use of a chemical dispersant. After that, the samples were centrifuged

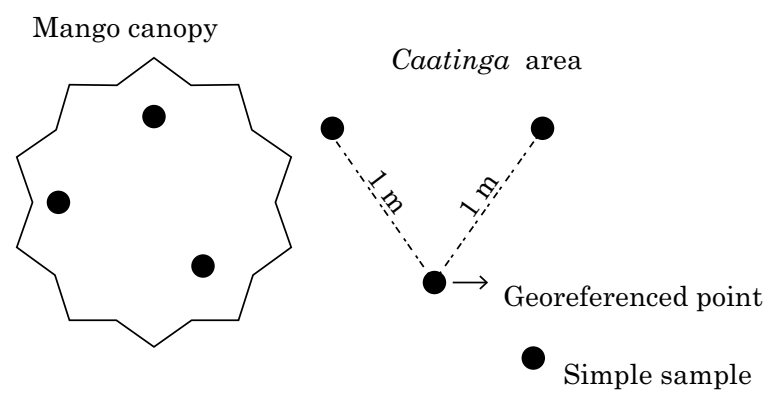

Figure 1. Sketch of collection of simple soil samples under the mango canopy and in the area of native caatinga. at $630 \mathrm{~g}$ for $15 \mathrm{~min}$ and the supernatant was passed through a sieve with 100 mesh $(0.149 \mathrm{~mm})$ for collection of the light organic matter fraction (LF). As the procedure adopted involves breakup of the aggregates through continuous shaking, before separation, the isolated LF is constituted by the inter- and intra-aggregate compartment (Sohi et al., 2001). The organic matter associated with the soil mineral components and that settled to the bottom of the centrifuge tube was considered the heavy fraction (WF). After separation, the LF was dried in a laboratory oven at $72^{\circ} \mathrm{C}$ for $72 \mathrm{~h}$ and then weighed. The organic $\mathrm{C}$ contents of the $\mathrm{WF}$ were determined by wet oxidation with external heating, according to the procedure proposed by Yeomans and Bremner (1988).

The $\mathrm{C}$ stocks in the SOM fractions were calculated considering the equivalent soil layer concept (Bayer et al., 2000). To do so, the C stocks of the soil under the mango tree were calculated for each layer, multiplying the results by the factor obtained by division of the soil $\mathrm{Bd}$ of the caatinga by the $\mathrm{Bd}$ under the mango tree. This factor was applied only to the $\mathrm{C}$ data in the soil under the mango. The $\mathrm{C}$ stocks at each soil depth were calculated by the use of the following formula: $\mathrm{C}$ stock $(\mathrm{t} / \mathrm{ha})=\mathrm{C}$ content $(\mathrm{g} / \mathrm{kg}) \times \mathrm{Bd} \times \mathrm{e} / 10$, in which Bd: soil bulk density at the depth $\left(\mathrm{kg} / \mathrm{dm}^{3}\right)$ and e: thickness of the soil layer $(\mathrm{cm})$.

After obtaining the data, descriptive analyses were carried out to obtain estimates of variance and application of the Student t test $(\alpha=5 \%)$ for the purpose of comparison of the mean values of the OC stocks of the soils under irrigated mango and native caatinga. It should be noted that the results of the analyses of soil OC did not take variation in depth in the treatments into account, but rather variation between the treatments in each soil layer evaluated. All the statistical analyses were carried out with the statistical program Sisvar 5.1 (Ferreira, 2007).

\section{RESULTS AND DISCUSSION}

\section{Organic carbon stocks}

The organic carbon (OC) stocks shown in the present study ranged from $3.8 \mathrm{t} / \mathrm{ha}$ (native caatinga, $10-20 \mathrm{~cm}$ depth) to $12.2 \mathrm{t} / \mathrm{ha}$ (irrigated mango, $0-10 \mathrm{~cm}$ depth) (Figure 2). The OC contents in the soil had a greater impact on variation of the stocks than bulk density, which had little variation (irrigated mango: 1.58 and $1.56 \mathrm{~kg} / \mathrm{dm}^{3}$, and native caatinga: 1.6 and $1.65 \mathrm{~kg} / \mathrm{dm}^{3}$ in the layers from 0-10 and 10-20 cm depth, respectively). The OC contents ranged from $2.29 \mathrm{~g} / \mathrm{kg}$ (native caatinga, $10-20 \mathrm{~cm}$ depth) to $7.47 \mathrm{~g} / \mathrm{kg}$ (irrigated mango, 0-10 cm depth), which were below the mean values (4.50-29.00 g/kg) found by Silva (2012) in an Argissolo Amarelo latossólico (Ultisol) of medium 
to clayey texture under irrigated mango and native caatinga in the region of Petrolina, PE, Brazil. The low clay content $(2.51 \mathrm{dag} / \mathrm{kg})$ of the Neossolo Quartzarênico (Quartzipsamment) provides less physical and/or colloidal protection to soil OC due to lack of formation of clay-organic complexes, resulting in low OC stocks (Tan et al., 2004). In physical protection (structural), OC is retained within the aggregates (especially microaggregates) of the soil, whereas in colloidal protection, there is close association of the organic matter functional groups with soil colloids (Caravaca et al., 2004). In the soil, soil organic matter is essential for water retention and nutrient supply, and it also affects soil physical properties (Cunha et al., 2005). Thus, due to this strong relationship of organic matter with other soil properties of different textures, it is important to use management techniques that maintain or increase soil organic matter content (Grigal and Vance, 2000).

Intervention in native vegetation for establishing agricultural crops may lead to a decline in soil OC due to an increase in the erosion process, acceleration of decomposition, reduction in the contribution of plant material, or differences in the quality of the residues (Bayer and Mielniczuk, 2008). The increases observed may occur due to plant growth or to management practices (Lugo and Brown, 1993). Various factors affect the magnitude and the speed with which these changes occur, including the type of soil use, type of soil, climate, and original vegetation (Post and Kwon, 2000).

The effect of the change of the type of land use led to a significant difference $(p<0.05)$ in the OC stock in the $0-10 \mathrm{~cm}$ soil layer when irrigated mango was compared to native caatinga (Figure 2). The soil under irrigated mango had an OC stock of
$12.22 \mathrm{t} / \mathrm{ha}$, whereas the soil under native caatinga had $7.92 \mathrm{t} / \mathrm{ha}$ of OC, an increase of $54.29 \%$ in the OC stock in irrigated mango. The high OC stock in the soil under irrigated mango was the result of the accumulation of organic residues on the soil surface coming from the mango trees, as visually observed in the area of study, and this was a $\mathrm{C}$ source for the soil (Costa et al., 2009). In addition, $20 \mathrm{~L} / \mathrm{pl}$ of goat manure is applied on an annual basis in the plant row (under the tree canopy). In contrast, a significant difference $(p<0.05)$ was not observed in the OC stock in the $10-20 \mathrm{~cm}$ depth layer. This is due to the fact that accumulation of soil OC occurs mainly in the uppermost soil layer, and is reduced in deeper layers of the soil profile (Bernard et al., 2007). A similar result was obtained by Coringa et al. (2010), who determined the OC stocks in Neossolo Quartzarênico (Quartzipsamment) under different plant covers. They observed that the OC stocks were inversely proportional to the depth evaluated. In a study carried out in Sergipe, Brazil, evaluating the impact of eight years of banana growing on the $\mathrm{SOM}$ of an Argissolo (Ultisol) in relation to native forest, Guimarães et al. (2014) observed that growing irrigated banana resulted in a $14 \%$ increase in the OC content. The greater OC contents found in the area of the banana plantation compared to the native forest area arise from the incorporation of crop residues (leaves and pseudostem) and of the plant material cleared off the area itself, together with the contribution of plant matter from herbaceous species.

\section{Carbon stocks in the humic substances}

The soil under irrigated mango showed greater $\mathrm{C}$ stocks in the fulvic acid fraction - FAF (1.32 t/ha), humic acid fraction - HAF (1.82 t/ha), humin fraction - HF (9.64 t/ha), and humic substances - HS (12.79 t/ha) (a)

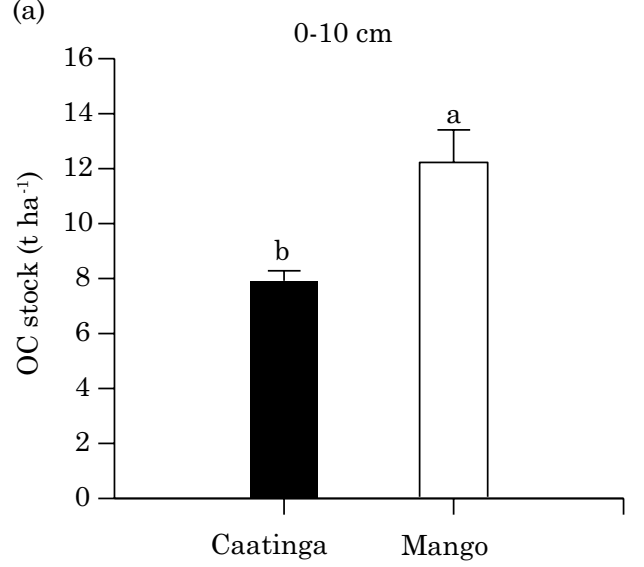

(b)

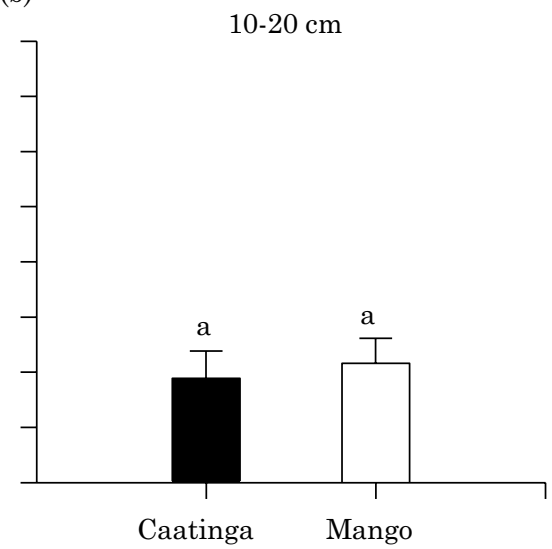

Figure 2. Organic carbon (OC) stocks in the 0-10 and 10-20 cm layers of soils under the growth of irrigated mango and native caatinga. Columns designated with the same letter do not differ by the Student $t$ test $(\alpha=5 \%)$. The vertical deviation bars represent the standard deviation of the mean. 

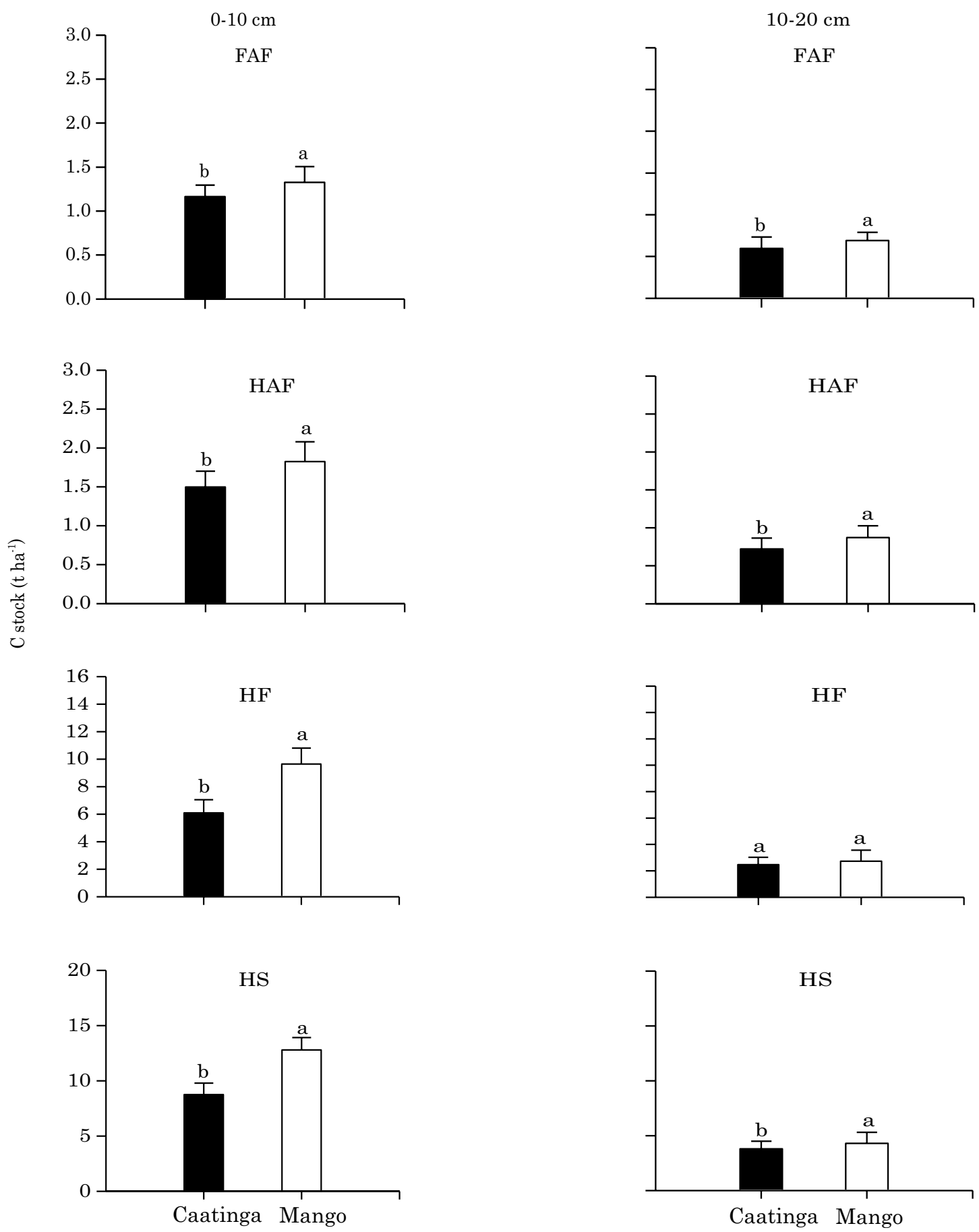

Figure 3. Carbon stocks in the fulvic acid fraction (FAF), humic acid fraction (HAF), humin fraction (HF), and humic substances (HS) in the 0-10 and 10-20 cm soil layers under irrigated mango and native caatinga. Columns designated by the same letter do not differ by the Student $t$ test $(\alpha=5 \%)$. The vertical deviation bars represent the standard deviation of the mean.

when compared to the soil under native caatinga $(\mathrm{FAF}=1.16 \mathrm{t} / \mathrm{ha}, \mathrm{HAF}=1.50 \mathrm{t} / \mathrm{ha}, \mathrm{HF}=6.09 \mathrm{t} / \mathrm{ha}$, $\mathrm{HS}=8.75 \mathrm{t} / \mathrm{ha}$ ) in the $0-10 \mathrm{~cm}$ depth layer (Figure 3 ). Similar behavior was observed for FAF, HAF, and HS in the $10-20 \mathrm{~cm}$ depth layer. Therefore, the deposit of organic residues over 20 years of mango growing favored an increase in $\mathrm{C}$ stocks in the humic substances in the soil. In irrigated mango areas, such as the São Francisco Valley region, especially in soils with low nutrient contents, fertilization for restoring the nutrients extracted by harvest may lead to an increase in primary productivity, such that greater 
quantities of plant matter may return to the soil and increase the $\mathrm{C}$ stocks of the humic fractions. Although experimental results are scarce for irrigated mango, analyzing information from various experiments, Johnson and Curtis (2001) observed that, in general, perennial crops (planted forests) with application of fertilizers showed greater contents of organic $\mathrm{C}$ in the soil.

Evaluating the impact of growing irrigated mango in comparison to native caatinga on medium texture/clayey Argissolo Amarelo (Ultisol) in Petrolina, PE, Silva (2012) observed that annual application of organic compounds (goat manure) in the area of irrigated mango resulted in an increase in the $\mathrm{C}$ contents of the humic fractions of soil organic matter when compared to native caatinga. Considerable water restriction, characteristic of semiarid environments under native caatinga vegetation, results in low plant biomass production, which results in reduction of organic residue input in the soil (Marin et al., 2006). In contrast, in irrigated mango orchards, this restriction does not occur, given that production of plant residue by high yielding mango is high. Thus, the input of organic matter (leaves, roots, plant material from pruning) in the soil over 20 years occurs with greater frequency and in a greater amount, favoring an increase in the stocks of organic matter in the soil, even in quite sandy soils, such as Neossolo Quartzarênico (Quartzipsamment).

After interference in native vegetation and a change in residue deposition in an ecosystem in a state of balance, there is the need for a new period of constant management practices so that soil organic matter attains a new point of stabilization. Under these new conditions of equilibrium, the stocks of organic matter may be less than, equal to, or greater than the stocks before the disturbance. This is a characteristic that depends on the type of soil, vegetation, and management practices (Swift, 2001). In a study carried out in soils planted to fruit-bearing plants, sugarcane, and vegetables in irrigated areas of Petrolina, PE, and Juazeiro, BA, Faria et al. (2007) found that the growing of vegetables, which are annual crops, contribute to reduction in OC contents in the soil, whereas the fruit-bearing plants and sugarcane contribute to increasing them, due to the input of organic residues provided by the management system for these crops.

In a system with an adequate technological level and a high planting density of irrigated mango, such as in the São Francisco Valley region, pruning, for the purpose of adequate production, constitutes a management practice carried out in each crop production cycle, resulting in deposition and maintenance of plant residues on the soil surface, contributing to an increase in the stocks of soil organic matter (Franzluebbers et al., 2007). In addition to the nutritional aspect, the maintenance of plant residues after pruning protects the soil from direct impact of raindrops, reducing the erosion process (Martins, 2005), avoiding erosion of the soil surface layer. Furthermore, the maintenance of plant residues increases soil moisture content and favors the supply of nutrients through mineralization of C-residues over time (Gonçalves, 2002). However, Caravaca et al. (2004), in a study carried out in Spain, observed that the soil under native forest showed a greater stock of $\mathrm{C}$ in the FAF and HAF in comparison to the soil under annual agricultural cropping. Production of annual crops with frequent soil turnover contributed to lower stocks of $\mathrm{C}$ in the humic fractions of the soil organic matter in relation to native vegetation.

According to Bayer and Mielniczuk (2008), under natural vegetation, soil organic matter remains stable. When subjected to agricultural use, there may be a sharp reduction in organic matter content, especially when tillage methods with intense soil turnover are used (exposing the soil organic matter to microbial action) and crop systems with low addition of crop residues. Reduction in soil organic matter has a negative effect on soil quality, and results in effects on nutrient cycling, lower activity of the biota, and less aggregate stability (Dantas et al., 2012). Areas under irrigated mango orchards are occupied by perennial crops without frequent soil turnover. Thus, they show higher OC and C stocks in the soil organic matter fractions. The absence of soil turnover in irrigated mango areas results in greater physical and chemical protection of the soil organic matter against microbial decomposition (Silva and Mendonça, 2007).

Carbon stocks in the humic fractions of the soil followed the decreasing order of $\mathrm{HF}>\mathrm{HAF}>\mathrm{FAF}$ (Figure 3). Similar results were observed by Piccolo (2002), who affirms that the C stock in the HAF is normally greater than the $\mathrm{C}$ stock in the FAF. In a study carried out in native cerrado (Brazilian tropical savanna), with conventional tillage and no-tillage in the southwest of Piaui in a Latossolo Amarelo distrófico (Oxisol), Campos et al. (2013) also observed that the $\mathrm{C}$ stock of the HF was predominant in relation to the $\mathrm{C}$ stock of the other humic fractions in the $0-5 \mathrm{~cm}$ layer. The FAF normally has great mobility in the soil profile (Silva and Mendonça, 2007), especially in a very sandy soil (clay content $=2.51 \mathrm{dag} / \mathrm{kg}$ ), such as Neossolo Quartzarênico (Quartzipsamment). In addition, the HF has the greatest humus content of the SOM, contributing to greater soil stabilization (biochemical protection) (Cunha et al., 2007). Evaluating the labile and recalcitrant fractions of soil organic matter in the $0-30 \mathrm{~cm}$ soil layer in a Latossolo Vermelho distróferrico (Oxisol) in an integrated crop-livestock system in Maracaju, MS, Brazil, Silva et al. (2011) observed that the HF was the most recalcitrant fraction of the soil organic matter, in comparison to HAF and FAF, regardless of the management systems and depths analyzed. 
The predominance of the HF in relation to the HAF and FAF corroborate the data obtained by Cunha et al. (2005), who analyzed the humic fractions of the soil organic matter of diverse soil types in Brazil. The HF of the soil organic matter is closely associated with the soil mineral fraction. The most probable means of formation of this fraction is through inheritance, which describes direct evolution of the lignified insoluble compounds present in the scarcely transformed organic matter and which essentially constitutes the inherited humin or residual humin (Duchaufour, 1977). Evaluating the HS composition of the soils of the Amazon, Lima (2001) observed the predominance of the HAF and HF, with a lesser contribution of the more soluble and mobile fractions (FAF). According to the author, this may be related to the intense humus formation and rapid mineralization of the organic matter. In addition, the accumulation of soil organic matter may contribute to an increase in the humic acid stocks through a process of inheritance of compounds of fresh organic matter, in a way similar to that which would occur to inherited humin, especially lignin (Stevenson, 1994).

In studies involving humic substances, the $\mathrm{C}_{\mathrm{HAF}} / \mathrm{C}_{\mathrm{FAF}}$ ratio may be considered an index of humus formation of the organic matter present in the soil (Souza and Melo, 2000), such that values greater than one indicate the predominance of polymerization of the organic matter. Differences were not observed in the $\mathrm{C}_{\mathrm{HAF}} / \mathrm{C}_{\mathrm{FAF}}$ ratio between the soils under irrigated mango and native caatinga in the 0-10 and 10-20 cm depth layers (Table 1). Nevertheless, numerically, all the values in reference to the $\mathrm{C}_{\mathrm{HAF}} / \mathrm{C}_{\mathrm{FAF}}$ ratio were greater than 1.0, which indicates that the environmental conditions of the region and the management of the area with irrigated mango favored humus formation, creating and accumulating HAF to the detriment of FAF in the soil profile, corroborating information from Ortega (1983). According to Orlov (1998), increase in the C stocks of HAF may be an indicator of improvement in the quality of the soil humus or of the increase in biological activity, which promotes the synthesis of more condensed humic substances. Similar results were observed by Ebeling et al. (2013); upon evaluating the $\mathrm{C}$ stock in humic fractions of diverse samples of Organossolo (Histosol) from different regions of Brazil, they observed that the values of the $\mathrm{C}_{\mathrm{HAF}} / \mathrm{C}_{\mathrm{FAF}}$ ratio were greater than 1 and concluded that the environmental conditions favored the stabilization of $\mathrm{C}$ in the HAF. In contrast, Leite et al. (2003) observed that the $\mathrm{C}_{\mathrm{HAF}} / \mathrm{C}_{\mathrm{FAF}}$ ratio was greater in the soil under native vegetation than in the soil under agricultural production systems, explaining that in natural forests, without disturbance of the soil, there is greater polymerization of humic compounds, increasing the proportion of the HAF in relation to the FAF. Cunha et al. (2007) also found values of HAF greater than FAF in Amazon forest soils. In the semiarid conditions under irrigated mango, the climatic factors, associated with the quality of the plant residue deposited, as well as the absence of frequent soil turnover, may have contributed to the process of humus formation of the soil organic matter, resulting in similar values for the $\mathrm{C}_{\mathrm{HAF}} / \mathrm{C}_{\mathrm{FAF}}$ ratio in the irrigated mango and native caatinga.

The $\mathrm{C}_{\mathrm{HF}} /\left(\mathrm{C}_{\mathrm{FAF}}+\mathrm{C}_{\mathrm{HAF}}\right)$ ratio indicates the direction of equilibrium of direct transformation between the humic fractions (Pizauro Junior and Melo, 1995), such that values greater than one indicate polymerization of organic matter in the direction of fulvic acids to humins. The soil growing irrigated mango showed a greater value of the $\mathrm{C}_{\mathrm{HF}} /\left(\mathrm{C}_{\mathrm{FAF}}+\mathrm{C}_{\mathrm{HAF}}\right)$ ratio (3.09) compared to the soil under native caatinga (2.29) in the 0-10 cm depth layer (Table 1), which indicates greater structural stability of soil organic matter under irrigated mango in this layer (Labrador-Moreno, 2002). In contrast, for the 10-20 cm depth layer, no difference was observed in the $\mathrm{C}_{\mathrm{HF}} /\left(\mathrm{C}_{\mathrm{FAF}}+\mathrm{C}_{\mathrm{HAF}}\right)$ ratio between the treatments evaluated. Thus, the effects of change in the type of land use from native caatinga to irrigated mango in regard to the structural stability of the soil organic matter were restricted to the uppermost soil layer. This result confirms that 20 years of accumulation of organic residues coming from irrigated mango, in general, favored a greater proportion of components of greater molecular weight in the uppermost soil layer,

Table 1. Values of the ratios $C_{\mathrm{HAF}} / \mathrm{C}_{\mathrm{FAF}}, \mathrm{C}_{\mathrm{HF}} /\left(\mathrm{C}_{\mathrm{FAF}}+\mathrm{C}_{\mathrm{HAF}}\right)$, and $\mathrm{C}_{\mathrm{FAF}}+\mathrm{C}_{\mathrm{HAF}}+\mathrm{C}_{\mathrm{HF}} / \mathrm{C}_{\mathrm{Total}}$ in the 0-10 and 10-20 cm soil layers under irrigated mango and native caatinga

\begin{tabular}{rrrr}
\hline Treatment & $\mathbf{C}_{\mathrm{HAF}} / \mathbf{C}_{\mathrm{FAF}}$ & $\mathbf{C}_{\mathrm{HF}} /\left(\mathbf{C}_{\mathrm{FAF}}+\mathbf{C}_{\mathrm{HAF}}\right)$ & $\mathbf{C}_{\mathrm{FAF}}+\mathbf{C}_{\mathrm{HAF}}+\mathbf{C}_{\mathrm{HF}} / \mathbf{C}_{\mathrm{Total}}$ \\
\hline & & $\%$
\end{tabular}

\begin{tabular}{|c|c|c|c|}
\hline & & $0-10 \mathrm{~cm}$ & \\
\hline Caatinga & $1.31 \mathrm{a}$ & $2.29 \mathrm{~b}$ & $110.35 \mathrm{a}$ \\
\hline \multirow[t]{2}{*}{ Mango } & $1.41 \mathrm{a}$ & $3.09 \mathrm{a}$ & $105.02 \mathrm{a}$ \\
\hline & & $10-20 \mathrm{~cm}$ & \\
\hline Caatinga & $1.24 \mathrm{a}$ & $1.91 \mathrm{a}$ & $102.94 \mathrm{a}$ \\
\hline Mango & $1.27 \mathrm{a}$ & $1.72 \mathrm{a}$ & $98.78 \mathrm{a}$ \\
\hline
\end{tabular}


which confirms the presence of organic matter of greater stability. Among the humic fractions, humin is the fraction with the most complex molecular structure and with molar mass greater than those of humic and fulvic acids (Silva and Mendonça, 2007).

Significant differences were not found in the values of the $\mathrm{C}_{\mathrm{FAF}}+\mathrm{C}_{\mathrm{HAF}}+\mathrm{C}_{\mathrm{HF}} / \mathrm{C}_{\text {Total }}$ ratio between irrigated mango and native caatinga (Table 1). This ratio provides information about the degree of humus formation of the soil organic matter. The values of the $\mathrm{C}_{\mathrm{FAF}}+\mathrm{C}_{\mathrm{HAF}}+\mathrm{C}_{\mathrm{HF}} / \mathrm{C}_{\text {Total }}$ ratio ranged from 98.78-110.35\%. Benites et al. (2003) reports that the range of variation may be from $98-105 \%$.

\section{Light fraction and heavy fraction carbon of the soil organic matter}

The stock of the light fraction (LF) of the soil organic matter was greater in the soil under irrigated mango $(\mathrm{LF}=2.01 \mathrm{t} / \mathrm{ha})$ in the first $10 \mathrm{~cm}$ of depth as compared to the soil under native caatinga $(\mathrm{LF}=0.66 \mathrm{t} / \mathrm{ha})$, but no difference was observed in the 10-20 cm depth layer (Figure 4). The LF of the soil organic matter is basically composed of partially decomposed plant residue, and it is strongly influenced by the quantity and quality of residue deposited on the soil (Six et al., 2002). Thus, the increase in LF, especially in the uppermost layer in the soil under irrigated mango in comparison to native caatinga, reflects the greater deposition of residues that occurs on the soil surface. This increase in the $\mathrm{C}-\mathrm{LF}$ in relation to native vegetation is important because, although its stock is normally less than other more stable fractions of SOM, it constitutes a compartment with rapid cycling that may favor the soil biota (Silva and Mendonça, 2007). This shows that the LF may be used as a sensitive indicator to detect changes in the quality of soil with different uses and management practices (Wu et al., 2004), although this greater stock of LF is not always seen (Leifeld and Kögel-Knabner, 2005).

The C stock of the heavy fraction (WF) of the soil organic matter was also greater in the soil under irrigated mango (WF $=8.12$ and $7.35 \mathrm{t} / \mathrm{ha}$ ) compared to the soil under native caatinga (6.04 and $3.72 \mathrm{t} / \mathrm{ha}$ ) for the 0-10 and 10-20 cm layers, respectively (Figure 4). The WF of the soil organic matter becomes important in soil $\mathrm{C}$ accumulation since it is more stable in response to changes in management practices due to its close association with the mineral fraction of the soil (Freixo et al., 2002). In a study carried out in the region of Machado, MG, Rangel (2006) also observed that the area under coffee cultivation provided for an increase in the $\mathrm{C}$ stock of the WF of soil organic matter compared to the native forest area.
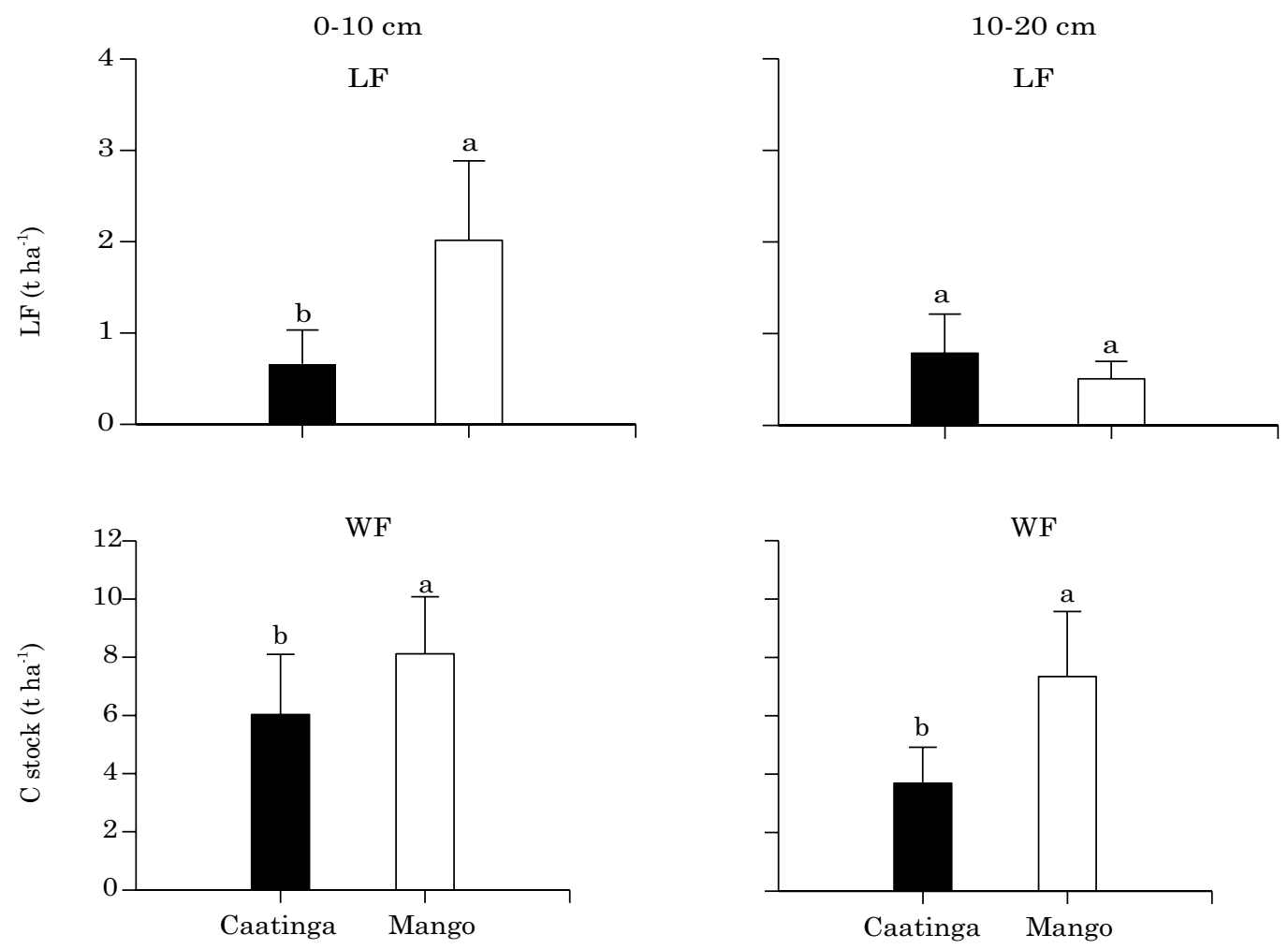

Figure 4. Light fraction (LF) and $\mathrm{C}$ stock of the heavy fraction (WF) of soil organic matter in the 0-10 and $10-20 \mathrm{~cm}$ layers of the soil under irrigated mango and native caatinga. Columns designated with the same letter do not differ by the Student t test $(\alpha=5 \%)$. The vertical deviation bars represent the standard deviation of the mean. 


\section{CONCLUSIONS}

Growing irrigated mango in an area previously occupied by native caatinga led to a greater stock of organic carbon, though this effect was restricted to the uppermost soil layer evaluated.

Growing of irrigated mango increased the carbon stocks of the fulvic acid fraction, humic acid fraction, humin fraction, and humic substances as compared to native caatinga. A similar behavior was observed for the carbon stock of the heavy fraction and for the light fraction.

The organic carbon, humic fractions, light fraction, and heavy fraction were indicators that were sensitive to changes in soil organic matter after establishment of irrigated mango growing in the Lower São Francisco Valley region.

\section{ACKNOWLEDGEMENTS}

The authors thank the Brazilian Council for Scientific and Technological Development (CNPq) for the partial financial support (CNPq 562698/2010-8).

\section{REFERENCES}

Albuquerque JAS, Medina VD, Mouco MAC. Indução floral. In: Genú PJC, Pinto ACQ, editores. A cultura da mangueira. Brasília: Embrapa Informação Tecnológica; 2002. p.259-276.

Alvarez V VH, Ribeiro AC. Calagem. In: Ribeiro AC, Guimarães PTG, Alvarez V VH, editores. Recomendações para o uso de corretivos e fertilizantes em Minas Gerais: $5^{\mathrm{a}}$. Aproximação. Viçosa, MG: CFSEMG, 1999. p.43-60.

Anuário Brasileiro da Fruticultura - Agrianual. Santa Cruz do Sul: Gazeta Santa Cruz; 2010.

Araújo Filho JA. Caatinga: Agroecologia versus desertificação. Ci Hoje. 2002;30:44-5.

Bayer C, Mielniczuk J. Dinâmica e função da matéria orgânica. In: Santos GA, Silva LS, Canellas LP, Camargo FAO, editores. Fundamentos da matéria orgânica do solo em ecossistemas tropicais e subtropicais. $2^{\mathrm{a}}$.ed. Porto Alegre: Metrópole; 2008. p.7-18.

Bayer C, Mielniczuk J, Amado TJC, Martin-Neto L, Fernandes SA. Organic matter storage in a sandy clay loam Acrisol affected by tillage and cropping systems in southern Brazil. Soil Till Res. 2000;54:101-9.

Benites VM, Mádari B, Machado PLOA. Extração e fracionamento quantitativo de substâncias húmicas do solo: um procedimento simplificado de baixo custo. Rio de Janeiro: Embrapa; 2003. (Comunicado técnico, 16).

Benites VM, Moutta RO, Coutinho HLC, Balieiro FC. Análise discriminante de solos sob diferentes usos em área de Mata Atlântica a partir de atributos da matéria orgânica. R Árvore. 2010;34:685-90.
Bernardi ACC, Machado PLOA, Madari BE, Tavares SRL, Campos DVB, Crisóstomo LA. Carbon and nitrogen stocks of an Arenosol under irrigated fruit orchards in semiarid Brazil. Sci Agric. 2007;64:169-75

Campos LP, Leite LFC, Maciel GA, Brasil EL, Iwata BF. Estoques e frações de carbono orgânico em Latossolo Amarelo submetido a diferentes sistemas de manejo. Pesq Agropec Bras. 2013;48:304-12.

Caravaca F, Lax A, Albaladejo J. Aggregate stability and carbon characteristics of particle-size fractions in cultivated and forested soils of semiarid Spain. Soil Till Res. 2004;78:83-90.

Carneiro MAC, Souza ED, Reis EF, Pereira HS, Azevedo WC. Atributos físicos, químicos e biológicos de solo de cerrado sob diferentes sistemas de uso e manejo. R Bras Ci Solo. 2009;33:147-57.

Claessen MEC, Barreto WO, Paula JL, Duarte MN. Manual de métodos de análise de solo. $2^{\text {a }}$.ed. Rio de Janeiro: Centro Nacional de Pesquisa de Solos; 1997.

Coringa EAO, Mendes CRJ, Oliveira TS, Felfili DMC. Determinação do carbono orgânico total e das frações húmicas de um Neossolo sob diferentes coberturas vegetais. In: Anais $50^{\circ}$ Congresso Brasileiro de Química; 2010, Cuiabá. Cuiabá: 2010. [Accessed on: Sep 11, 2013]. Available at: http://www.abq.org.br/ cbq/2010/trabalhos/5/5-468-8191.htm.

Costa OV, Cantarutti RB, Fontes LEF, Costa LM, Nacif PGS, Farias JC. Estoque de carbono do solo sob pastagem em área de Tabuleiro Costeiro no sul da Bahia. R Bras Ci Solo. 2009;33:1137-45.

Cunha TJF, Canellas LP, Santos GA, Ribeiro LP. Fracionamento da matéria orgânica humificada de solos brasileiros. In: Canellas LP, Santos GA, editores. Humosfera: Tratado preliminar sobre a química das substâncias húmicas. Campos dos Goytacazes: Universidade Estadual do Norte Fluminense; 2005. p.54-80.

Cunha TJF, Madari BE, Benites VM, Canellas LP, Novotny EH, Moutta RO, Trompowsky P, Santos GA. Fracionamento químico da matéria orgânica e características de ácidos húmicos de solos com horizonte A Antrópico da Amazônia (Terra Preta). Acta Amaz. 2007;37:91-8.

Dantas JDN, Oliveira TS, Mendonça ES, Assis CP. Qualidade de solo sob diferentes usos e manejos no Perímetro Irrigado Jaguaribe/Apodi, CE. R Bras Eng Agríc Amb. 2012;16:18-26.

Demolinari MSM, Silva IR, Lima AMN, Vergutz L, Mendonça ES. Efeito da solução de separação densimétrica na quantidade e qualidade da matéria orgânica leve e na quantificação do carbono orgânico da fração pesada. R Bras Ci Sol. 2008;32:871-9.

Duchaufour P. Pedology. London: George Allen \& Unwin Publication; 1977.

Ebeling AG, Anjos LHC, Pereira MG, Valladares GS, Pérez DV. Substâncias húmicas e suas relações com o grau de subsidência em Organossolos de diferentes ambientes de formação no Brasil. R Ci Agron. 2013;44:225-33.

Faria CMB, Silva MSL, Silva DJ. Alterações em características de solos do Submédio São Francisco sob diferentes sistemas de cultivo. Petrolina: Embrapa Semiárido; 2007. (Boletim de pesquisa e desenvolvimento, 74).

Ferreira DF. Sistemas para análise de variância para dados balanceados - SISVAR (versão 5.1). Lavras: Universidade Federal de Lavras, 2007. (Software).

Franzluebbers AJ, Schomberg HH, Endale DM. Surface-soil responses to paraplowing of longterm no tillage cropland in the Southern Piedmont - USA. Soil Till Res. 2007;96:303-15. 
Freixo AA, Machado PLOA, Guimarães CM, Silva CA, Fadigas FS. Estoques de carbono e nitrogênio e distribuição de frações orgânicas de Latossolo do cerrado sob diferentes sistemas de cultivo. R Bras Ci Solo. 2002;26:425-64.

Gama-Rodriguez EF, Barros NF, Gama-Rodriguez AC, Santos GA. Nitrogênio, carbono e atividade da biomassa microbiana do solo em plantações de eucalipto. R Bras Ci Solo. 2005;29:893-901.

Gonçalves JLM. Conservação do solo. In: Gonçalves JLM, Stape JL, editores. Conservação e cultivo de solos para plantações florestais. Piracicaba: IPEP; 2002. p.47-129.

Grigal DF, Vance ED. Influence of soil organic matter on forest productivity. J For Sci. 2000;30:169-205.

Guimarães DV, Gonzaga ME, Melo Neto JO. Manejo da matéria orgânica do solo e estoques de carbono em cultivos de frutas tropicais. R Bras Eng Agríc Amb. 2014;18:301-6.

Johnson DW, Curtis PS. Effects of forest management on soil C and N storage: Meta analysis. For Ecol Manage. 2001;140:227-38.

Labrador-Moreno J. La materia orgánica en los agrosistemas. Madrid: Mundi-Prensa Libros; 2002.

Labrador-Moreno J. La materia orgánica en los agrosistemas. Madrid: Ministeria Agricultura: 1996.

Leifeld J, Kögel-Knabner I. Soil organic matter fractions as early indicators for carbon stock changes under different land-use. Geoderma. 2005;124:143-55.

Leite LFC, Mendonça ES, Neves JCL, Machado PLOA, Galvão JCC. Estoques totais de carbono orgânico e seus compartimentos em Argissolo sob floresta e sob milho cultivado com adubação mineral e orgânica. R Bras Ci Solo. 2003;27:821-32.

Lima HN. Gênese, química, mineralogia e micromorfologia de solos da Amazônia Ocidental [tese]. Viçosa, MG: Universidade Federal de Viçosa; 2001.

Lugo AE, Brown S. Management of tropical soils sinks or sources of atmospheric carbon. Plant Soil. 1993;149:27-41.

Marin AMP, Menezes RSC, Silva ED, Sampaio EVSB. Efeito da Gliricidia sepium sobre nutrientes do solo, microclima e produtividade do milho em sistema agroflorestal no agreste paraibano. R Bras Ci Solo. 2006;30:555-64.

Martins SG. Erosão hídrica em povoamento de eucalipto sobre solos coesos nos Tabuleiros Costeiros-ES [tese]. Lavras: Universidade Federal de Lavras; 2005.

Mendham DS, Heagney EC, Corbeels M, O'connell AM, Grove TS, Mcmurtrie RE. Soil particulate organic matter effects on nitrogen availability after afforestation with Eucalyptus globulus. Soil Biol Biochem. 2004;36:1067-74.

Orlov DS. Organic substances of Russian soils. Eur Soil Sci. 1998;31:946-53.

Ortega FS. El humus de los suelos de Cuba: I. Suelos derivados de esquistos ácidos. Ci Agric. 1983;17:63-89.

Piccolo A. The supramolecular structure of humic substances: a novel understanding of humus chemistry and implications in soil science. Adv Agron. 2002;75:57-134.

Pizauro Junior JM, Melo WJ. Influência da incorporação da parte aérea de sorgo ou lab-lab nas frações da matéria orgânica de um Latossolo Vermelho-Escuro. R Bras Ci Solo. 1995;19:95-103.

Post WM, Kwon KC. Soil carbon sequestration and land-use change: Processes and potential. Global Change Biol. 2000;6:317-27.
Rangel OJP. Estoques e frações da matéria orgânica e suas relações com o histórico de uso e manejo de Latossolos [tese]. Lavras: Universidade Federal de Lavras; 2006.

Roscoe R, Machado PLOA. Fracionamento físico do solo em estudos da matéria orgânica. Dourados: Embrapa Agropecuária Oeste; 2002.

Santos HG, Almeida JA, Oliveira JB, Lumbreras JF, Anjos LHC, Coelho MR, Jacomine PKT, Cunha TJF, Oliveira VA. Sistema brasileiro de classificação de solos. $3^{\text {a }}$.ed. Rio de Janeiro: Embrapa Solos; 2013.

Silva DJ, Quaggio JA, Pinto PAC, Pinto ACQ, Magalhães AFJ. Nutrição e adubação. In: Genú, P.J.C, Pinto, A.C.Q., editores. A cultura da mangueira. Brasília: Embrapa Informação Tecnológica; 2002. p.192-221.

Silva EF, Lourente EPR, Marchetti ME, Mercante FM, Ferreira AKT, Fujii GC. Frações lábeis e recalcitrantes da matéria orgânica em solos sob integração lavoura-pecuária. Pesq Agropec Bras. 2011;46:1321-31.

Silva IR, Mendonça ES. Matéria orgânica do solo. In: Novais RF, Alvarez V VH, Barros NF, Fontes RLF, Cantarutti RB, Neves JCL, editores. Fertilidade do solo. Viçosa, MG: Sociedade Brasileira de Ciência do Solo; 2007. p.274-374.

Silva JR. Frações da matéria orgânica do solo devido ao uso de compostos orgânicos em um Argissolo Amarelo no semiárido brasileiro [dissertação]. Mossoró: Universidade Federal Rural do Semiárido; 2012.

Six J, Conant RT, Paul EA, Paustian K. Stabilization mechanisms of soil organic matter: Implications for C-saturation of soils. Plant Soil. 2002;241:155-76.

Sohi SP, Mahieu N, Arah JRM, Powlson DS, Madari B, Gaunt JL. A procedure for isolating soil organic matter fractions suitable for modeling. Soil Sci Soc Am J. 2001;65:1121-8.

Souza WJO, Melo WJ. Teores de nitrogênio no solo e nas frações da matéria orgânica sob diferentes sistemas de produção de milho. R Bras Ci Solo. 2000;24:885-96.

Stevenson FJ. Humus chemistry: Genesis, composition and reactions. $2^{\text {nd }}$.ed. New York: John Wiley \& Sons; 1994.

Swift RS. Organic matter characterization. In: Sparks DL, Page AL, Helmke PA, Loeppert RH, Soltanpour PN, Tabatabai MA, Johnston CT, Sumner ME, editors. Methods of soil analysis. Madison: Soil Science Society of America, American Society of Agronomy; 1996. p.1011-20.

Swift RS. Sequestration of carbon by soil. Soil Sci. 2001;166:858-71.

Tan ZX, Lal R, Smeck NE, Calhoun FG. Relationships between surface soil organic carbon pool and site variables. Geoderma. 2004;121:187-95.

Universidade Estadual do Norte Fluminense - Uenf. [Accessed on: Sept 25, 2013]. Available at: http://www.uenf.br/uenf/centros/ cct/qambiental/so_comporg.html.

Wu T, Schoenau JJ, Li F, Qian P, Malhi SS, Shi Y, Xu F. Influence of cultivation and fertilization on total organic carbon and carbon fractions in soils from the Loess Plateau of China. Soil Till Res. 2004;77:59-68.

Yeomans JC, Bremner JM. A rapid and precise method for routine determination of organic carbon in soil. Commun Soil Sci Plant Anal. 1988;19:1467-76. 